\title{
Civilisations
}

Revue internationale d'anthropologie et de sciences

humaines

44 | 1997

Les peuples des forêts tropicales

\section{Bibliographie des ouvrages cités}

\section{OpenEdition \\ Journals}

Édition électronique

URL : http://journals.openedition.org/civilisations/1636

DOI : 10.4000/civilisations. 1636

ISSN : 2032-0442

\section{Éditeur}

Institut de sociologie de l'Université Libre de Bruxelles

\section{Édition imprimée}

Date de publication : 1 janvier 1997

Pagination : 238-252

ISBN : 2-87263-122-4

ISSN : 0009-8140

Référence électronique

"Bibliographie des ouvrages cités », Civilisations [En ligne], 44 | 1997, mis en ligne le 29 juin 2009, consulté le 19 avril 2019. URL : http://journals.openedition.org/civilisations/1636 ; DOI : 10.4000/ civilisations. 1636 


\section{BIBLIOGPAPHIE DES OUVHAGES CITÉS}

ACEVEDO, R. \& CASTRO, E., 1993. - Negras do Trombetas: guardiães de matas e rias. Belém, UTPANAEA.

ALBERT, B., 1992. - Indians lands, environmental policy and military geopolitics in the development of the Brazilian Anazon: the case of the Yanomami. In : Development and change, vol. 23:35-70. London, Sage.

ALEXANDRE, P. \& BINET, J., 1958. - Le groupe dit Pahouin (Fang, Boulou. Béti). Coll. Monographies ethnologiques africaines de l'Institut International Africain, 152 p. Paris: PUF.

ANDERSON, D. \& GROVE. R., 1987. - Introduction: The scramble for Eden: past, present and future in African conservation. In: Anderson D. \& Grove R. (Eds), Conservidion in Africa. People. policies and practice: 1-13. Cambridge: Cambridge University Press.

ANDERSON, J. 1824. - Political and commercial considerations relative to the Mallavan Peninsula

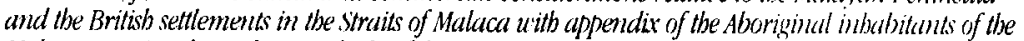
Makayan I'eninsula and perticularly' of the Negritos called Semang. Prince of Wales Islands: East Indian Company's Civil Service.

ANONYME, 1983. - 0 Índio e a cidadania, Comissão Pró-fndio. São Paulo, Editora brasiliense.

ANONYME, 1991. - Povos Indígenas no Brasil : 87,88,89,90, Aconteceu especial, 18. São Paulo: CEDI.

ANTHROPOLOGY RESOURCE CENTER/ARC., 1981. - The Yanomami Indian Park: a call for action. ARC: : Boston. 
BAHARON, A.R., 1967. - Marketing of Orang Asli Produce. Jabatan Hal tihwal Orang Asli : Kuala Lumpur.

BAHARON, A.R., 1976. - The Temuans and the Wider Society : Integration and Assimilation in M. D. Dahlan (Ed.) The Nescent Malaysiam Sociely. Kuala Lumpur : Dept. of Anthropology/Sociology, U.K.M.

BAHUCHET, S., 1985 - Les Pygmées Aka et la forêt centrafricaine. Paris: SBIAF.

BAHUCHET, S., 1991 - Spacial mobility and access to resources among the African pygmies. In : Casimir, M.S. and Rao, A. (Eds), Mobility and lerritoriality. New York : Berg.

BAlluCHET, S., 1992. - Dans la forêt d'Afrique centrale. les Pygmées Aka et Baka. (Histoire d'une cinilisution foressière l) Paris: Peeters-Selaf.

BAHUCHET, S., 1993. - L'invention des Pygmées. Cabiers d'Etudes Africaines, 129, T. 33(1) : 153-81.

BAHUCHET, S. \& I): MARET P. (sous la direction de), 1994a. - Situation des propulations indigènes des forêts denses et bumides. Luxembourg : Office des Publications officielles de la Commission des Communautés Européennes.

BAHUCHET, S. \& IDE. MARFT P. (dirigida por), 1994b. - Situacion de las Poblaciones indigencus de los bosgues densas bumedos... Luxembourg : Office des Publications officielles de la Commission des Communautés Européennes.

BAHUCHET, S. \& IF MARET P. (under the supervision of), 1994C. - State of indigenous Populations biring in rainforest arecas. luxembourg: Office des Publications Officielles de la Commission des Communautés Européenıes.

BAHUCHET, S., \& al., 1994. - Synthèse des interactions entre l'Homme et la forêt tropicale. In: Bahuchet, S. \& de Maret; P. - Situation des populations indigènes. . : : 11-83.

BALLEY, R.C. \& DEVORE I., 1989. - Research on the Efe and Lese propulations of the Ituri Forest, 7aire. American journal of Plysical Anthropology, vol. 78: 459-471.

BALLEY, R.C. \& PEACOCK N.R., 1988 - Efe Pygnies of Northeast Zaire: subsistence strategies in the Ituri Forest. In : de Garine I. \& Ilarrison G.A. (Eds), Coping' uith uncertainty in food supply, 88-117. Oxford: Oxford Iniversity Press.

BAILEY, R.C. \& HFADLAND T.N., 1991. - The tropical rain forest: Is it a productive environment for human foragers? Human Ecology, vol. 19, 2: 261-285.

BALEE \& POSEY, 1989. - Resource management in Amazonia: indigernous and folk strategies. Adtrances in economic botany, vol. 7. New York: New York Botanical Society.

BASTIDE, R., 1967. - les Amériques Noires. Paris: P.J.F.

BEBWA, B., 1993. - Ecologie quantitative des jeunes stades de la reconstitution forestière en région Équatoriale, Thèse de doctorat, Laborotaire de Botanique Systématique et de Phytosociologie. Université Libre de Bruxelles.

BEETS, W.C., 1990. - Raising and suskining productivity of smallholder farming systems in the tropics. Alkmaar, Holland: AgBé Publishing.

BENJAMIN, G., 1976. - Austroasiatic subgroupings and prehistory in the Malay Peninsula. In P. Jenner et al.(Eds), Austroastulic Studies: 37-128. Hawaii: Univ. Press.

BINSWANCER, H.P., 1986. - Evaluating research system performance and targeting research in landabundant areas of Sub-Saharan Africa. World Det elopment, vol. 14, no $0^{\circ}: 469-475$. 
BIRRAUX-ZIEGLER, P. 1992. - Les Yanomami, la forêt et les Blanes. Géngrapbie et Cultures, $n^{\circ} 4$.

BIRRAIX-ZIEGLER, P. 1989-1990. - Protection de la nature at indigénisme. Ouelques réflexions à propos des droits territoriaux des Yánomanni au Brésil et au Vénézuela. Bulletin de la Société suisere des Américanistes, $\mathrm{n}^{\circ}$ 53-54.

BROWN, K.S., \& BROWN G.C., 1992, - Habitat alteration and species loss in Brazilian Forests. In: Whitmore T.C. \& Sayer, J.S. (Eds), Tropical deforestation and species extinction - UICN. London: Chapman \& Hall.

BU.RKILI., I.H., 1966. - A dictionary of the ecomomic products of the Malay Peninsula, 2 volumes. Kuala L.umpur: Ministry of Agriculture and Co-operatives.

CALDWELL, J.C. \& CALDWELL. P. 1990. - High fertility in Sub-Saharan Africa: birtll rates and population growth have begun to decline everywhere else in the developing world what makes this region different?, Ścientific American, May: 82-89.

CANT, R.G., 1973. - An bistorical geograpby of Pabang. Kuala Lumpur: Malaysian Branch Royal Asiatic Society, Monograph $\mathrm{n}^{\circ} 4$.

CAREY, I., 1979. - The resettlement of the Orang Asli from a historical perspective. Federation Museum jotmual, vol. 24 (N.S.): 159-169.

CENTRO ECLIMENICO DE DOCLMENTACAO/CEDI Et PROJETO ESTUDO SOBRE TERRAS

INDIGENAS/PETI, 1990 - Tetras indígencas no Brasil. São Paulo et Rio de Janeiro.

CHAMPAUD, J., 1973. - Mom: Kerroir Bassa (Cameroun), Atlas des Structures Agraires au sud du Sahara, $n^{\circ}$ 9. Paris: ORSTOM.

CLASTRES, P., 1974. - La Société contre litut: recherches d'antbropologie politique, Paris: lid. de Minuit.

CI.EAVER, K. \& al. (Eds), 1992. - Conservation of West Central Rainforest. Colloque d'Abidjan. World Bank Environment, Paper 1 .

COLCHESTER, M., 1993. - Forest peoples and sustainability. In : Colchester, M. and Iehman L., (Eds), The siruggle for land and the fate of the forests. Penang, Malaysia: World Rainforest Movement.

COICHESTER, M., 1994. - Saltaging nature: indigenous peoples, protected areas and biodiversity conservation. LNRISD/World Rainforest MovenentwWI: Miméo, International Discussion Paper 55. Geneva: UNRISD.

COLLINS, J.T., 1980. - Laha, a language of the central Moluccas. Indonesia Circle 23:3-19.

COLLINS. J.T., 1984. - Linguistic research in Maluku: a report on recent fieldwork. Oceanic Linguistics 20, $1-273-146$.

CONKLIN, H. C., 1980 - Ethmographic attas of If ugero. London: New Haven.

CONSEJO NATIONAL INDIO DE VENEZUIELACONIE et UNUMA. s.d. - Ley Orgúnica de Protección a las Etmias, Ciudualanos Indígenas. Caracas: Projet de loi miméographié.

CORNER, E.J.H., 1952. - Wayside Trees of Malaya, 2 volumes. Singapore : Gov't Printer.

CORRY, S., 1993. - Harvest moonshine, taking you for a ride: a critique of the 'rainforest harvest', its theory and practice. Sum iral for rribal peoples: London: Survival International (special issue).

COTE, S., 1992.- Plan de zonage préliminaire. Cas du Cameroun Méridional. Objectifs et méthodologie. République du Cameroun: Poulin Theriault Inc. Canada/Ministère de l'Environnement et des Forêts. 
CRAMB, R.A., 1993. - Shifting cultivation and sustainable agriculture in East Malaysia: A longitudinal case study. Agricullural sistems, vol. $42: 209-226$.

DA CUNHA, E., 1993. - Llaules terres: la guerre de Canudes, trad. de Os Sertôes, par Coli, J. et Seel A. Paris: Métaillé (Eds).

DA CLINHA, M. CARNEIR0, 1990. - l'Etat, les Indiens et la nouvelle Constitution. In: Bruce, A. (Eds), Brésil: Indiens el déreloppement en Amazonie, Eithries: 11-12.

DA MATTA, R., 1993 - - Autour de la représentation de la nature au Brésil: pensées, fantaisies et divagations. In: Bourg D. (sous la direction de), Les sentiments de la nature, 215-27. Paris: La [lécouverte/essais.

DE COENE, R., 1956. - Agricultural settlement schemes in the Belgian Congo. Tropical Agriculture, vol. $33: 1-12$.

IEE GARINE, I., 1991a. - Les interdits alimentaires d'origine sociale et religieuse. Rerue du praticien, 41(11): 973-6.

DE: GARINE, I., 1991b. - Ecological success in perspective f. Hum. Kcology, 1: 55-72.

DEF GARINE, I., 1994. - The diet and nutrition of human populations. In Ingold, T. (Ed.), Compranion encyclopedia of anthropology'. London and New York, Routledge: 226-64.

DE WACHTTR, P., 1995. - Agriculhure itinérante Badjoúé chons la Réserve de Faune du Dja KBsCamerouny. 'Thèse de Maîtrise, Faculté de Sciences Agronomiques et Sciences Biologiques Appliquées. Katholieke Universiteit leuven.

DECARIE, J., BIRRAIX, P., COLIINS, M. \& GAIIDRAU G., 1977. - Les réserves écologiques: origine. significution et porkée. Montréal: Centre de recherche et d'inmovations urbaines, Université de Montréal.

DENTON, R.K., 1968. - The Semui : a non-liolent people of Malata. Itolt, Rinehart, \& Winston: New-York.

[OETHER, M., 1995. - Etude Chasse. Rapport ECOFAC- Cameroun, AGREC,O-CTFT.

J)ESCOLA, P. 1986. - Ia nature domestique, symbolisme et praxis dems l'Ecologie des Achuar, Paris: Ed. de la Maison des Sciences de l'Honme.

DIFFI.TH, G., 1979. - Asian languages and Southeast Asian Prehistory. Feteration Museum Joumul (N.S.) 24:3-18.

DONNER, W., 1987. - Latud tase and entironment in Indonesia. London: Hurst.

DOUNIAS, E., 1992. - Pratique agroforestière des agriculteurs de la réserve de Campo: à l'interface des ressources naturelles et des ressources cultivées. In: Kabala, M.D., Bedel, J. \& Nine, T. (sous la direction de), Actes du séminaire régional: gestion des ressources et des résertes de la biosphère et éducation relatize à l'entironnemenl (projet pilote de Dja): 198-211.

DOUNIAS, E., 1993. - Dynamique et gestion différentielles du système de production à dominante agricole chez les Mucue du Sud Cameroun forestier. These de doctorat. Université de Montpellier II.

DOVE, M.R., 1983a. - Forest preference in swidden agriculture. Tropical Ecology 24, (1) : 122-42.

DOVE, M.R., 1983b. - Theories of swidden agriculture and the political economy of ignorance. Agroforestry Systems 1, (3):85-99.

DOVE, M.R., 1993. - A revisionist view of tropical deforestation and development. Environmental Conservation 20, (1): $17-24$. 
DRACHOUSSOFF, V. FOCAN, A. \& HECQ, J., (Eds), 1992. - Le dételoppement rural en Afrique Centrale 1908-1960/1962. Synthèse et réflexions, 2 vols. Leuven, Paris: Fondation Roi Baudouin.

DRANSFIEL.D, J., 1979. - A Mamual of the Rattans of the Malay Peninsula, Forest Dept. : West Malaysia.

DRIESSEN, P.M. \& DLDAL, R. (Eds), 1991. - The Major soils of the world Agricultural University Wageningen (Netherlands), Department of Soil Science and Geology in association with Katholieke Universiteit leuven (Belgium), Institute for Land \& Water Management.

DUNN, F.L., 1975. - Rainforest collectors and traders, a study of resource utilization in modem and ancient Malaya, Journal of the Malaysian branch Royal Asiatic Society $\mathrm{n}^{\circ} 5$.

DUPRIEZ, H. \& de IEENER, P., 1993. - Arbres et cultures multiétagées d'Afrique. Nivelles, Belgique: Terres et Vie, et Paris: L'Harmattan.

DVORÀK, K.A., 1992. - Resource management by West African farmers and the economics of shifting cultivation, Amer. J. Agr. Econ., August: 8(99-815.

ECOFAC, 1993a. - Rléments caractérisiaucs de la démograpbie des Badjoués de la Réserne de Fanne du Dja sur base da recensement de mars 1993. Yaoundé: ECOFAC-Cameroun.

ECOEAC, 1993b. - Carte forestière (Canton Dja). Yaoundé: ECOFAC-Cameroun.

EDWARDS, 1.1)., 1993. - Introduction. In: Edwards, I.D., Macdonald, A.A. \& Proctor J. (Eds), Natural bistory of Seram, Maluku, Indonesia. Andover: Intercept.

EDWARDS, I.D., PROCTOR, J. \& RISWAN, S., 1993. - Rainforest types in the Manusela national park. In: Edwards, L.D., Macdonald, A.A. \& Proctor J. (Eds), Natural bistory' of Seram, Maluku, Indonesia. Andover: Intercept.

EIDE, A., 1994. - Intervention à la sous-commission de prérention de la discrimination et de la protection des minorilés. ONU. Minéo.

ELLEN, R.F., 1973. - Nuaulu settlement and ecology: an approach to the environmental relations of an eastern Indonesian communit?: Inpublished thesis submitted for the degree of Doctor of Philosophy in the University of Iondon.

ELLEN, R.F, 1977. - Resource and commodity. Problems in the analysis of the social relations of Nuaulu land use. J. Anthr. Research 33: 50-72.

ELIEN, R.F, 1978. - Nuaulu selllement and ecology: an afproach to the entironmental relations of an eastern Indonesian community (Verhandelingen van het Koninklijk Instituut voor Taal-, land- en Volkenkunde 83). The Hague: Martinus Nijhoff.

ELLEN, R.F, 1979. - Sago subsistence and the trade in spices. A provisional model of ecological succession and imbalance in Moluccan history: In : Bumham, P. \& Ellen, R.F. (Eds), Social and ecological systems, ASA Monographs in social anthropology, 18. London : Academic Press.

ELLEN, R.F., 1985. - Patterns of indigenous timber extraction from Moluccan rainforest fringes Journal of Biogerography $12: 559-87$.

ELLFN, R.F., 1986. - What black elk left unsaid: on the illusory images of green primitivism. Antbropology Today 2, (6 Decenber) : 8-12.

EILLEN, R.F., 1987. - Environmental perturbation, inter-island trade and the re-location of production along the Banda arc; or, why central places remain central. In: Suzuki, T. and Ohtsuka R. (Fds), Human ecologn' of bealth and sumvial in Asia and the South Pacific. Tokyo: University of 'Tokvo Press. 
EIIEN, R.F., 1988, - Foraging, starch extraction and the sedentary lifestyle in the lowland rainforest of central Seram. In: Ingold. T., Riches, D. \& Woodburn J. (Eds), Hunters and gutberers 1: history, enolution and social change. London: Berg.

EL.LEN, R.F., 1993a. - Human impact on the environment of Seram. In: Edwards, I.D., Macdonald, A.A. \& Proctor J., Natural bistory of Sircam. Maluku, Inclomesia. Andover: Intercept.

ELLIFN, R.F., 1993b. - Rhetoric, practice and incentive in the face of the changing times: a case study of Nuaulu attitudes to conservation and deforestation. In: Milton, K. (Ed.), Environmentulism: the view from anthropology! !ondon: Routledge

ENDICOTT, K., 1974. - Batek Negrito Economy and Social Organization. Unpublished Ph. D. Dissertation, Cambridge : Harvard University.

ENDICOTT, K., 1975. - A brief report on the Semaq Beri of Pahang. Federation Museum Journal Vol $20: 1-25$.

ESCAIANTE, A., 1971. - Ia mineria del bambre. Bogotà.

FVANS, I.H.N., 1915. - Notes on various aboriginal tribes in Negri Semblian, Journal of the Federated Malcy States Museums, 6:101-115.

EVANS, I.IIN., 1920. - Customs of the camphor hunters. Joumal of the Federated Malay States Museums, 9:53-59.

FERRETTI, M., 1991. - O caboclo no tambor de mina e na dinâmica de um terreiro de São Luís: a casa de Fanti-Asbanti. Thèse de Doctorat, Université de Sào Paulo.

FERRETTI, S., 1991. - Repensando o Sincretismo. Estudo sobre a Casa des Mincas. Thèse de Doctorat, Université de São Paulo.

FERRY, L., 1993. - L'héritage du cartésianisme et l'approche française de la nature le droit des animaux. In : Bourg D. (sous la direction de) : Les sentiments de la nature. Paris: La Découverte/essais, 215-27.

FOXWWRTHY, FW., 1922. - Minor forest products of the Malay Peninsula. Malayan Forest Records, $n^{\circ} 2,151-217$.

FRESCO, L.0., 1986. - Cassava in Shiffing Cultivution : A Systems Aptroach to Agricullural Technology Derelopment in Africa, Roval 'Tropical Institute, Ansterdam.

GAISSEAU, P., 1959/1960. - The sky above the mud below. Film. Paris.

GALVÃO, 1976. - Santos e visagens, um estudo da vida religiosa de Itán Baixo Amazonas. São Paulo : Ed. Nacional.

GANY0, G.Y., 1985 - L'organisation de l'espace agricole chez les ntumu Béti du Woleu Ntem, Muntu, 3: $41-68$.

GIANNO, R., 1990. - Stemelai Culture and Resin Tecbnology, Memoirs of the Connecticut Academy of Arts and Sciences, vol. XXII.

GIEL, J.W., 1935-6. - Het boschproduct 'gom-copal' der wouden op Halnahera en Niew-Guinee. Tropisch Nederland 8, 363-5.

GOODLAND, R., 1982. - Tribal peoples and economic development. Human ecologic considerations. Washington: World Bank.

GOSS, J.D., 1992. - Transmigration in Maluku: notes on present condition and future prospects.

Cakalele, Maluku Research fournal 3, 87-98 
GRENAND, F., 1982. - Fl l'Homme den inl jayuar: univers imaginaire et quotidien des Indions Woncäri de Gulyane. Paris: Lillarmattan.

GRENAND, F. \& GRENAND, P., 1990. - L'identité insaisissable: les Caboclos amazoniens. In: Identité et sociétés nomades: symboles, normes et transfomationts, Bourgeot A. \& Guillaume. H., (tids). Études Rurales, 120: 17-40.

GRENAND P. \& GRENAND, F., 1995 - Vivre dans l'abondance: forêt pensée et forêt vécue chez les Wayampi (Amérindiens de Guyane). In: Etude comparative de la représentation symbolique des arbres..., 8-27.

CROS, C., 1991. - Colombia indigena, Cerec, Bogotà.

GROUPE D'ETLIDE DES POPULATIONS FORESTIERES EQUA'TORIALES, 1995 - Etude comparative de la représentation symbolique des arbres et de la forôt éfuatoriale fror quelquas populations indigènes. Rapport pour la I)(i XI, Conmission Européenne.

GROVE, R., 1987.- Early themes in African conservation: the Cape in the nineteenth century. In: Anderson D. \& Grove R., (Eds), Consemation in Africa. People. politicies and pratice. Cambridge: Cambridge Eniversity Press, 21-41.

GRZIMEK, B.R.0., 1992. - From subsistence gardening towards cash-cropping with trees: changes in the farming system practised by former cultivators in eastem Indonesia. Onersects Derelopmenl institute, Rural Develofmenl Forestry' Neturork Pajer 13d, $1-12$.

GUILLOT, B. \& DIALLO, Y., 1984. - Systèmes agraires et cultures commerciales. L'exemple de Boutazab (région de la Sangha au Congo). Cabiers de /ORS\%OM, Coll. Atlas des structures agraires au sud du Sahara, 20.

GUTELMAN, M., 1989. - L'agriculture itinérante sur brûlis, la Recherche, vol. 20, n²26, 1464-1474.

HAM, S.P., 1911. - Over de damarwinning op Obi. Fectona 4, 205-238, 301-339.

HAMILTON, A, 1989. - African Forests. In: Lieth, H. \& Werger, M.J.A., (Eds), Ecosystems of the World 14B: Tropical Rainforest Ecosystems, Elsevier, Amsterdam.

HARDJONO, J., 1991. - The dimensions of Indonesia's environmental problems. In: Indonesia: resources, ecology and entironment. Jlardjono, J., (Eds), Oxford: Oxford University Press.

HARRIS, D., 1969. - Agricultural systems, ecosystems and the origin of agriculture. In: The Domestication and Exploitation of Plants, Ucko, P.J. \& Dimblely, G.W., Duckworth: London.

HART. JA, 1978. - From Subsistence to Market: a case study of Mbuti net hunters. Human Ecology, vol.6(3):325-253.

HART, J.A. \& HART, T.B., 1986. - The Ecological Basis of Hunter-Gatherer Subsistence in African Rain Forests: 'The Mbuti of Eastem Zaire. Humun Ecology, vol. I4(1):29-55.

HECKETSWEILER, P., DOUMENGE, C. \& MOKOKO IKONGA. J., 1991 - Le parc National d'Odzala, Congo. Gland, Suisse et Cambridge. Royaume-Uni: UICN.

HEMMING, J., 1978. - Red Gold: the conquest of the Braziliuns Indians. London, Macmillan.

HEMMING, J., 1987. -Amazon Frontier: the defeat of the Brazilian Indians. London, Macmillan.

HIEKPO, P. \& SCHIEFENHÖVEL, W., 1987. - Mensch und Pflanze. Ergebnisse ethnotaxonomischer und ethnobotanischer Untersuchungen bei den Eipo, zentrales Bergland von Irian Jaya (West-Neuguinea) Indonesien. Reiner, Berlin. 
HLAI)IK, C.M.. BAHICHET. S. \& de GARINE, I., 1989. - Se nourrir en forêl équatoriale. Antbropologie alimentaire cles populations des régions forestiòns bumides d'Afrique. Paris: LNESCO/MAB.

HIADIK, C.M., HLADIK, A., LINARES, 0.F, PAGEZT, H., SEMPLE, A. \& HADLEY, M., 1993. - Troprical foreshs. people and food. Biocullural interactions an applications to development. Paris, New York: IINESCO/The Parthenon Publishing Group.

HOOKER, M.B., 1990. - The Orang Asli and the Laus of Malaysia: wilb special reference to land. Symposium Ketiga: Mengenai Kehidupan Sosial dan Pembagunan Masyarakat Orang Asli di Semenanjung Malaysia, Universiti Kebangsaan Valaysia, Bangi.

HOWELL., S., 1984. - Society and Cosmos:The Cheuong of Peninsular Malaysia, Oxford University Press: Singapore.

HUNTER, T.M. \& NTIRI, G.K., 1978. - Speculations on the future of shifting agriculture in Africa. joumal of Deteloping Areas, vol. 12(2): 183-208.

IIURST, P., 1990. - Rainforest politics: ecological desiruction in southeast Asia. London: Zed Books.

IHUYBENS, E. \& 'TOLIENS, E.F., 1987. - Rice Production in the Rainforest in Zaire: An Analysis of the Smallholder Traditional Faming System in Yalibwa, Upper-Zaire, Agricultural Systems, vol. 31, 291-303.

ICIIIKAWA. M., 1991. - The Impact of Commoditization on the Mhuti of Eastern Zaire. Senri bilbnological sinuties $30: 135-162$.

IITA, 1993. - Anmual Report 1993, Ibadan, Nigeria.

ISACSSON, S.E., 1974. - Biografia Atratema. Berlin: Ibero-Amerikanisches Institut Preussischer Kulturbesitz.

JENSEN, KE., 1977. - Relative Age and Category: The Semaq Beri Case, Folk, vol. 19:171-181

JEWSIEWICKI, B., 1983. - Rural society and the Belgian colonial economy, In: Bimingham, D. \& Martin, Ph.M., (Eds) Itistory of Cemtral Africa. vol. 2. Iondon, New York.

JOHNSON, A, 1975. - Time Allocation in a Machiguenga Community. Etbnology 14(3):301-310.

JOIRIS, D. V., 1993a - Baka Pygmy hunting rituals in southern Cameroon: how to walk side by side with the elephants. Cin ilisations, $31 / 1-2: 51-89$.

JOIRIS, D. V., 1993b. - The mask that is hungry for yams: Ethmo-ecology of Dioscorea Mangenotiana among the Baka, Cameroon. In Hladik. Hladik, Linares, Pagezy. Semple et Hadley (Eds). Tropical forests. People and Food. Bioculturd interactions and appliations to derelopment. Paris, INESCO et Parthenon Publishing Group, 633-42.

J(OIRIS, D. V., 1996a - Comparative approach to hunting rituals among Baka Pygmies (Southeastern Cameroon). In: Cullural Diversity Amons Iu entieth Centuary Foragers: An African Perspective. Cambridge: Cambridge University Press, 245-75.

JOIRIS, D. V., 1996B. - Ce que «bien manger» veut dire chez les Pygmées Kola (Gyeli) et Baka du SudCameroun. In: Froment A., De Garine I., Binam Bikoi Ch. et LoungJ.F., Bien manger et bien vitre... Paris: L'Ilamattan-()RSTOM, 365-370.

JOIRIS, D.V \& BAHUCHET, S., 1994. - Afrique Equatoriale. In : Situation des /opulations indigènes des forêts denses bumides, Luxembourg: Office des Publications Officielles de la Commission des Communautés Européennes, 387-441.

JOIRIS, D.V \& TCHIKANGWA, B., I995. - Systèmes fonciers et socio-politiques des populations de la Réserve de Faune du Dja. Approche anthropologique pour une gestion en collaboration avec les villageois. Rapport ECOFAC-Cameroun, AGRECO - C'CFT. 
JONES, P., 1976. - Foresiry (Technical report no.7). Jakarta: East Indonesia regional development study. JIRION, F. \& HENRY, J., 1967. - De l'Agriculture linérante à l'Agricullure Intensifiée, Publications de I'Institut National pour l'Ftude Agrononique au Congo (I.N.E.A.C.), Hors Série.

KANG, B.T., WILSON, G.F. \& LAWSON, T.L., 1984. - Alley C'ropping : A Stable Alternative to Shifting Cultivation, Intemational Institute of Tropical Agriculture (IITA), Ibadan, Nigeria.

KANTOR KECAMATAN AMAHAI, 1983. - Laporan Tabunan. Amahai.

KANTOR SENSUS DAN STATISTIK PROPINSI MALUKU, 1972. - Sensus Penduduk 1971. Ambon.

KANTOR SENSUS DAN STATISTIK PROPINSI MALUKU, 1980. - Registrasi Penduduk Propinsi Mahuku 1978. Ambon.

KANTOR SENSUS PROPINSI MALUKU, 1980. - Maluku Dalam Angka 1980. Ambon.

KANTOR STATISTIK KABUPATEN MALUKU TENGAH, 1984. - Maluku Tengah dalam angka 1983. Masohi.

KANTOR STATISTIK PROVINSI MALUKU, 1989. - Maluku dalam angka 1988, Ambon.

KARIY, WAZIR-JAHAN BEGIIM, 1981. - Ma' Betisik Concepts of Liting Things (LSE Monographs on Sicial Anthropology). London: Athlone Press.

KOCH, G., 1977. - Die Fipo: Anatomie einer Steinzeitkultur. Bild der Wissenschaft 9: 44-59.

KHOO THEAM ENG., 1979. - Health Priorities in the resettlement of Orang Asli. Federation Museum journal, vol. 24 (NS) : 177-81.

KORN, V.E., 1917. - Het damarbedriff in het Sultanaat van Batjan. Tijdschrift voor bet Binnenlandsch Bestuur 51, 277-95.

KLICHIKURA, Y., 1987. - Subsistence Foology among Semay Beri Hunter Gatherers of Peninsular Malaysia Hokkaido. Behavioural Science Rejort Series E, no 1 June, Hokkaido University: Sapporo.

LAHM, S., 1993. - Itilization of forest resources and local variation of wildlife populations in northeastem Cabon. In: Hladik, C.M., Hladik, A. Linares, O.F., Pagez, H. Semple, A.\& Hadley, M. (Eds), Tropical Forests, People and Food: Biocullural hnteractions and Ajplications to Detelopment. MAB series 13, 691-707, Unesco (Paris) and Parthenon Publishing Group.

LAHM, S., 1994. - The Impact of the elephants on agriculture in Gabon. Programme WWF pour le Gabon/CE (DG VIII), Libreville.

Laporan expedisi ilmiah lembah-X. 2 Okt. sampai dengan 20 Des. 1969 di Irian Barat. Komando Daerah Militer XVII “Cenderawasih ». Mimeo. Jayapura.

IAVELEYE, D., 1995. - L'espace social néo-amazonien: sy'mbolisme et pratis dans l'écologie des communatutés "négro-caboclas " du Maranbäo, Brésil, Thèse de DFA, Université de Paris X-Nanterre.

LAWRENCE, P., 1964. - Road belong cargo. Carlton, Manchester and Melboume University Press, Melboume.

LEACOCK, E., 1978. - Women's status in egalitarian society: implications for social evolution. Currenl Antbropology, 19:247-75

IEACOCK, E., LEE, R. B. (Eds) 1982. - Politics und History in Band Societies. Cambridge University Press. LEE, R. B. \& DEVORE I., (Eds), 1968. - Man the Hunter. Chicago: Aldine Press. 
LEPINIDFUR, A., 1985. - Deux Communications sur l'Agriculture des Paysans dans la Zone Forestière Camerounaise, Mimeo, IRAT-CIRAI), Montpellier, krance.

LEPIAIDEUR, A., LONGUEPIERRE, G. \& WAGUEIA, A. 1981. - Modèle 3C': Cameroun Centre-sudCacaoculture, IRAT, Montpellier.

LEVI-STRAUSS, C., 1962 - le totémisme aujourdhui. Paris: Presses Universitaires de France.

LEVI-STRAUSS, C., 1955. - Tristes Tropiques. Paris: Plon.

IEVT-STRALSS, C., 1993. - Un autre regard. In: «La remontée de l'Amazone : antbropologie et bistoire des sociétés amazoniennes. Paris: LHomme., 126-128 XXXIII.

I.EVI-STRAUSS, C., 1994. - Saudes do Brazil, Paris, PU.F.

LOSONCZY, A.M., 1986. - Ie destin des guerriers - Agression chamanique et agression guerrière chez les Enberà du Choco. Paris: Joumal des Américanistes. Musée de l'Homme, 157-183.

LOSONCZY, A.M., 1990. - La maitrise du multiple. Corps et espace dans le chamanisme enberà du Choco. Paris: L'Homme 113: 75-100.

LOSONCZY, A.M., 1992. - les Suints et la Forêt. Système social et système rituel des Négro-Colombiens :échanges inter-elbniques avec les Embera chi Choco. Thèse de Doctorat, Université Libre de Bruxelles.

LOSONCZY, A.M. \& 7EMPLENI, A., 1991. - Anthropologie de la 'patrie' : le patriotisme hongrois. Terrain $17,29-38$.

MACANDREWS, C., 1986. - land policy in modern Indonesia. Boston: Lincohn Institute of Land Policy.

MALONEY, B.K., 1993. - Climate, man and thirty thousand years of vegetation change in north Sumatra. Indonesian Enironmental History Neusletter 2, 3-4.

MARTOIIRDJO, H.S., 1988. - The Tugutil hunter-gatherers of central Halmahera and national development programme in Indonesia. Zagreb: Paper presented at the 12th International Congress of Anthropological and Ethnological Sciences.

MARX, K.. 1972. - Capilal vol. III, Progress Publishersin: Moscow.

MAUSS, M., 1950. - Essai sur Je don : forme et raison de l'échange dans les sociétés anchaïques. In Sociologie et antbropologie. Paris: P.U.F. (145-279).

MCCLURE, J.N., 1969. - An estimation of a bird population in the primary forest of Selangor, Malaysia, Malaysian Nature Journal 22:179-183.

MCNEELY, J.A. et al. 1990. - Conserving the worlds biological diversity. World Bank/IUCN, $194 \mathrm{p}$.

MEDWAY, Lord, 1978. - The Wild Animals of Malaya and Singapore, 2nd edition, Oxford Iniversity Press: Kuala Lumpur.

MEDWAY, Lord., 1963. - Pocket Checklist of the Birds of Malaya and Singapore. Malayan Nature Society : Kuala Lumpur.

MEILIASSOUX, C., 1981. - Maidens, Meal and Money: Capitalism and the Domestic Community. Cambridge University Press: Canibridge.

WILIER, 1969. - The Spice Trade of the Roman Empire: 29 B.C. to A.D. 641 0xford: Clarendon Press.

MINAGRI, 1990. - Recueil de Données Technico-Economiques de Production, Budgets de Cultures: 'Zone Agro-Ecologique Forestière (Provinces du (Centre, du Sud et de l'Fst), MINAGRI, Yaoundé. 
MINISTERIO DAS MINAS E ENFRGIA, 1975. - Projeto Radambrasil. N 8. Departamento Nacional de Pesquisa Mineral/INPM, Rio de Janeiro.

MINISTERIO DEL AMBIENTE Y DE LOS RECURSOS NATURAIES RENOVABLES, 1991 - Decreto No 1635 del $1 / 8 / 1991$, Caracas.

MIRACLE. M. 1967. - Agriculture in the Congo Basin. Tradition and Change in African Rurral Economies, Madison.

MORAN, E.r., 1981. - Dereloping the Amazon. Bloomington (Indiana, USA) Indiana University Press.

NATIONAL RESFARCH COUNCIL, 1993. - Sustumable Agriculture and the Environment in the Humid Tropics. Washington D.C. : National Academy Press.

NEWTON, A., 1989.-Central Africa, a travel sumiral kit. Hawthom lictoria, Australia. Innely Planet Publications.

NOONE, H.D., 1936. - Report on the Settlements and Welfare of the Ple-Temiar Senoi of Perak-Kelantan Watershed. Federation Museum Jonrnal, 19:1-84.

NOONE, R.D., 1955. - Notes on trade in blowpipes and blowpipe bamboo in North Malaya, Federation Museum Joumal 1-2:1-18.

NORGAARD, R.B., 1981. - Sociosystem and Ecosystem Coevolution in the Anazon, Journal of Entironmental Economics and Management, vol. 8, 238-254.

NORGAARD, R. B., 1987. - Economics as mechanics and the demise of biological diversity, Ecological Modelling, vol. 38, 107-121.

NUGENT, S., 1993. - Amazonian Caboclo sociely: an essay in invisibility and peasant economy. Oxford: Berg Ph,

OKIGBO, B. N., 1986. - La Culture Itinérante en Afrique Tropicale: Définition et Iescription. If : LArenir de la Culture Itinérante en Afrique et les Tâches des Uninersitess. Rome: PAO.

ORMELING, F., 1947. - Bosbouw op Ceram. Economisch Weekblad 13, (14), 226-7.

ORSTOM \& UNESCO, 1983. - Ecasystèmes Forestiers Tropicaux d'Afrique. Paris.

PACHECO DE OLIVEIRA, J., 1990. - Les Tikuna et leur lutte pour la terre, Eitmies, 11-12: 136-142.

PAGEZY, H. \& GUAGLIARIDO, V., 1992. - Rôle du sumaturel dans la gestion des ressources naturelles chez, les Ntomba du Zaire. Ecoloyie bumaine, 10-1, 69-77.

PARKER, 1985. - The Amazon cuboclo: bistorical and contemporary perspectives. Studies in third world societies 32. Williansburg: College of William and Mary.

PIMBERT, M.P. \& PRETTY, JN., 1995. - Penple and Professionals. Putting "Participation" into protected areas management. International Discussion Paper n'57. Geneva: UNRISD.

INRISD/hnternational listitute for Environment and DevelopmentuWWF.

POTTER, L., 1991. - Environmental and social aspects of timber exploitation in Kalimantan, 1967-1989. In: Indonesial : resources, ecology and emironment. Hardjono, J., (Eds), Oxford: Oxford University Press.

PIJTMAN, P., 1948. - The Pygmies of the Ituri Forest. In: C.S.Coon. (Ed.) A Reader in Genereal Antbropology. New York. 322-342. 
RAMBO. A. T., 1979. - Human Ecology of the Orang Asli: A Review of the Research on the Environmental Relations of the Aborigines of Peninsular Malaysia. Federation Museum Joumal (N.S.) $24: 41-75$.

RAMOS A., 1943. - Introdução à Antropologia Brasileira. Rio de Janeiro: C.E.B.

REY, P.P. \& DUPRE, G., 1973. - Reflections on the pertinence of a thenry of history of exchange, Economy and Society, $11,2$.

RIBEIRO, D., 1986. - Os findios e a civilizagão: a integraģão das populacõos indígenas no Brasil moderno Petrópolis: Ed. Vozes.

RICHARDS, P, 1985. - Indigenous Agricultural Revolution: Ecology and Food Production in West Africal Iondon: Ilutchinson.

RIEM, J.I., 1913(1909) - Verslag van een onderzoek naar de doos de bevolking van Morotai en eenige streken van Halmaheira uitgeoefende rechten op damarbosschen. Adutrechtbundels 7, 110-20.

ROBERCIIEK, C., 1980. - Cognatic Kinship and Territoriality annong Semai-Senoi Feteration Museum Journal (N.S.) 25:89-102.

ROOSEVELT, C., 1993. - The rise and the fall of Amazon chiefdoms. LHomme, 126-128, XXXIII (2-4): $255-283$

RÖSIIER, M., 1992. - Pygmäenforschung und kein Ende? Kritische Betrachtungen zum Verhältnis von Bauern und Bambuti im Ituri-Gebiet von Haut Zaire. In: Müller E.W \& Brandstetter A.M. (Eds), Forschungen im äquatoriakn Afrika: in memoriam Erika Sulzmann. Miunster, Hambury.

RÖSLER. M., 1997. - Regenu'aldfeldbau im Ituri. Agrarsystem und. Soziöikonomie einer Gemeinde im Nordosten Yaires. München.

RUSHFORTH, S. 1976. - Recent Land Use by the Greal Bear Lake Indians. Evidence presented to the Mackenzie Valley Pifeline inquiry. Yellowknife.

SACHS, I., 1993. - L'écodéveloppement. Paris: Syros.

SAHLJNS, M.D., 1972. - Stone Age FConomics. Chicago: Aldine-Atherton.

SANCHEZ, P., 1976. - Properties and Menagsement of Soils in the Iropics. New York: John Wiley \& Sons.

SATO, Il., 1983. - Hunting of the Boyela, slash and burn agriculturists, in the Central Zaïre forest. African Study Monographs, 4: 1-54.

SALINIER, T., 1962. - Tussen be'mel en moeras. Zenen manden duars onbekende gebieden tan Nieuu' G'uinea. Dee Tijdstroom \& Pont Royal.

SAUTTER, G., 1966. - De l'Atlantique au fleune Congo. Une géograpbie de sous-peuplement. 2,1. Paris: Lahaye, Mouton et $C^{\circ}$.

SCHATZBERG, M. C., 1988. - The Dialectics of Oppression in Zatire. Bloomington.

SCHEBESTA, P., 1973. - Among the Forest Dutarfs of Malaysia, 0xford: Iniversity Press.

SCHIEFENI1ÖVEL, W., 1976. - Die Eipo-Ieute des Berglands von Indonesisch-Neuguinea. Homo 26 (4): $263-275$.

SCHIEFENHÖVEL, W., 1989. - Reproduction and sex-ratio manipulation through preferential female infanticide among the Fipo in the Highlands of West-New Guinea In: Rasa, $\Lambda$, Vogel, Ch. \& Voland, E.,

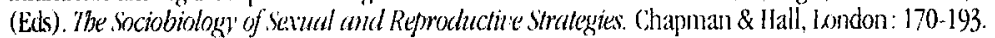


SCOTT, J.C., 1985. - Weatons of the Weak: Everyday forms of Peasant Resistance Yale University Press, New Haven.

SECRETARIA GENERAL DO CONSEIHO DE SEGURANCA NACIONAL/SG-CSN, 1985 - Projet (Catha Norte. Desenvolvimento na região ao norte das calhas dos rios Solimões e Amazonas. Brasilia, mimén

SECRETT, C., 1986. - The environmental impact of transmigration. The Ecologist 16, (2-3).

SERAN, 1922. - Serun (Mededelingen van het Bureau voor de Bestuurszaken der Buitenbezittingen, bewerkt door het Encyclopaedisch Bureal 29). Weltevreden: Kolff.

SILVESTRE, P., 1989. - Cassatca. London: CTA \& Macmillan.

SKEATS, W.W., 1900. - Malay Magic: and introduction to the folklore and popular religion of the Malay Peninsula, New York Dover.

SKEATS, W.W. \& BLAGDEN, C.0., 1906. - Pagan Races of the Malay Peninsula, 2 vol. I.ondon: Frank Carr and Co, Lid.

SKEPHI, 1992. - Logging and the sinking island. Inside Indonesia 33, 23-5.

SKEPHI \& KIDDELL-MONROE, R., 1993. - Indonesia: land rights and development. In 7be struggle for land and the fute of the forests. (Eds) Colchester, M. and I.. Lohmann. Penang, Malaysia: World Rainforest Movement.

TANNER, A., 1979. - Bringing Home the Animals: Religious Ideology and the Mode of Production of the Mistussini Cree /lunlers, Institute of Social and Economic Research Memorial University:

Newfoundland.

TERASHIMA, H., 1985. - Variation and Composition Principles of the Residence Group (band) of the Mbuti Pygmies - beyond a typical/atypical dichotomy. African Study Monographs. Supplementary Issue $4,103-120$.

TERASHIMA, H., 1986. - Economic Exchange and the Symbiotic Relationship between the Mbuti (Efe) Pygmies and the Neighbouring Farmers. Sprache und Geschichte in Afrika, vol.7(1):391-405.

THOMAS, J.M.C. \& BAHUCHET S. (Eds), 1981 - Encyclopédie des Pyymées Aka - Techmiques, langage et société der chasseurs-cueilleurs de la forêt centrafricaine. Paris: SEIAF-Peeters, 15 vol.

THOMAS, S.C., 1991. - Population Densities and Patterns of Habitat Use among anthropoid primates of the lturi Forest (Zaïre), Biolropica 23: 68-83.

TIBBETTS, G.R., 1956a. - The Malay Peninsula as known to the Arab geographers, Malayan J. Tropical Geography' 9:21-60.

TIBBETTS, G.R., 1956b. - Pre-Islamic Arabia and South-East Asia. J. Malayan Branch Royal Asiatic Sociely 29(3):182-208.

TIBBETS, G.R., 1957. - Early Muslim traders in South-East Asia.J. Malayan Branch Royal Asiatic Siociet? 30(1):1-45.

TONDEUR, G., 1957. - l'agriculture nomade au Congo belge. Bruxelles.

TRIANA, A, 1987. - Estado-nacion y minorias etnicas. In: Grupas etnicas, derecho y cultura, Funcol, Bogota.

TURNBEIL, C.M., 1965. - Wavrurard Sernants. the two uorlds of the African Pygmies. New York: The Natural History Press. 
TURNBUII., C.M., 1968. - The Importance of flux in hunting societies. In: Lee, R. B. and Devore, I. (Eds) Man the Hunter. Chicago: Aldine. Press.

TURNBULL, C.M., 1983. - The Mbuli Pygmies: change and adaptation. New York: Holt, Rinehart and Winston.

TWEEDIE, M.W.F, 1956. - Prebistoric Malaya. Third edition. Singapore: Eastem Universities Press.

TWEEDIE, M.W.E. \& HARRISON, J.L., 1954 - Malayan Animal Life. London: Iongmans.

UICN, 1994. - Resolutions and Recommendations. 19th Session of the General Assembly of IUCN.

VAN GELUWE, II., 1956. - Les Bira et les peuplades limitrophes. Annales du Musée Royal du Congo Belge, Monographies elbnograpbiques, vol. 2. Tervuren.

VAN GELUWE, H., 1959. - Les Bali et les peuplades apparentées (Ndaka-Mho-Beke-Lika-Budu-Nyari). Annales du Musée Royal du Congo Belge, Monographies ethnographiques, Vol. 5. Tervuren.

VANSINA, J., 1990. - Paths in the Rainforests. Toward a History of Political Tradition in Equatorial Africa. London.

VARGAS, P., 1993. - Los Embera y los Cuna: Impacto y reaccion ante la ocupacion espanola. Siglos $X V I y V I I$. CEREC/Instituto Colombiano de Antropologia, Bogota.

VASCO, L.C., 1985. - Ins Faibunas: los verdaderos hombres. Bogota: Banco Popular.

VAYDA, A.P., 1981. - Research in east Kalimantan on interactions between people and forestsIn : a preliminary report. Bormeo Research Bulletin 13, (1), 3-15.

VISSER, L.E., 1989. - My ricefield is my child: social and territorial aspects of surdden cultiration in Sabu, eastern Indonesia (Verhandelingen 136). Dordrecht, Holland-Providence, USA; Foris.

WWAKYANAKAZI, M., 1991. - Import and Export in the Second Economy in North Kivu. In: MacGaffey, Janet (Eds): The real economy of Zaire: an anthroplogical situdy. Philadelphia.

WEHLE, E., 1986. - Efe (Mbuti Pygny) Relations to the Lese Dese Villagers in the Ituri Forest, Zaire: historical Changes during the L.ast 150 Years. Sprache und Geschichte in Afrika, 7(2):375-411.

WANG, G., 1958. - The Nanhai trade: A study of the early history of Chinese trade in the South China Sea. Journal of the Malayan Branch Royal Asialic Society 31 (2) :1-135.

WASHBURN, W.E. (Ed.), 1988. - History of Indian-White relations. In: Honabook of North American madians, vol. 4, Washington. Smithsonian Institution.

WEST, R.C., 1957. - The Pacific Loulands of Colombia: A Negroid Area of the American Tropics. Bâton Rouge: Louisiana State University Press.

WESTPHAL, E., 1981 ou 85. - Cullures Viurières tropicales avec Référence spéciale au Cameroun. Pudoc, Pays-Bas, Wageningen.

WIFATLEY, P., 1959. - Ceographical notes on some commodities involved in Sung maritime trade. J. Maluyan Branch Royal Asialic Socity 32(2):1-140.

WHEATTEY, P., 1961. - The Golden Khersonese. Kuala Lumpur: Iniversity of Malaya Press.

WHEATLEY, P., 1964a. - Impressions of the Malay Peninsula in Ancient Times, Singapore: Eastern Universities Press. 
WHFATLEY, P., 1964b. - Desultory remarks on the ancient history of the Malay Peninsula Chapter 2, p. 33-75. In: Medayan and Indonesian Studies. Essans Presented to Sir Rickard Winstedt on bis Eigblyfifth Birthedey. Bastin J. and Roolvink R. (Eds). Oxford: Clarendon Press.

WhIFATI.EY, P., 1970. - Review: The Spice Trade of the Roman Empire: 29 B.C. to A.D. 641. by Miller J. I. J. Asian Studies 29: 677-678.

WHITEHEAD, N., 1993. - Ethnic transformation and historical discontinuity in native Amazonia and Guayana, 1500-1900.L'Homme, 126-128, XXXIII (2-4): 285-305.

WHITMORE, TC., 1979. - Palms of Mulaya. Kuala Lunjpur: Oxford University Press.

WHITMORE, TC., 1992. - An mtroduction to Tropical Rain Forests. Oxford, Clanendon Press.

WHITTEN, N., 1974. - Black Frontiers man: a soutb-american case. New York.

WIISSE, B. 1980) - Zaire. Lamdestutur - Berö̈lkerung - Wirtscbuft. Wissenschaftliche Länderkunden Bet. 15. Damstadt.

WILKIE, D.S. \& FINN, J.T., 1990. - Slash-burn cultivation and mammal abundance in the Ituri forest (Zaire), Biotropica, vol. 22(1), 90-99.

WIISON, F..0., 1993 - La diversité de la rie Paris: Editions Odile Jacob.

WINDSTEDT, R.0., 1920. - The camphor language of Johore and Southern Pahang. Journal of the Federated Malay States Museums. 9(1):59-81.

WITTE, J., 1992. - Deforestation in Zaire: Logging and Landlessness, The Ecologist, vol. 22, $\mathrm{n}^{\circ} 2$.

WOODBURN, J., 1980. - Fgalitarian Societies, Man, 17:431-51.

WORLD BANK, 1992. - World Derelopment Report. Washington.

YOUNG, C., 1965. - Politics in the Congo. Decolonizalion and Independence. Princeton.

YOUNG, C. \& TURNER, T., 1985. - The rise and decline of the Zairian state. Madison. 